\title{
Sovereign Wealth Funds' Affiliation and Acquisition Premium: Evidence from the Asia-Pacific Region
}

\section{Ali Awais Khalid*, Ghulame Rubbaniy ${ }^{* *}$, Muhammad Faisal Rizwan $^{* * *}$, Hassan Rauf Chaudhry ${ }^{* * *}$}

\begin{abstract}
This study aims to extend the signaling theory, by offering the buy-side sovereign wealth fund's (SWF) affiliation as a signal of the acquisition premium. Using the mergers and acquisitions (MEAs) deals' data from Asia-Pacific, over the period from 2000-2017, the results reveal that the effect of buy-side SWF's affiliation, on the acquisition premium of target firms is negative, and statistically significant in the North Asian region. Our cross-country analysis shows a negatively significant effect of the buy-side SWF's affiliation on the acquisition premium in China. The findings of our sectoral analysis report a significantly adverse effect of $S W F^{\prime}$ 's affiliation on the acquisition premium in the energy and cyclical goods sector. This suggests that the SWFs are likely to be more influential in MEAs deals that are conducted in the strategic sectors. Our findings demonstrate that the buy-side SWF's affiliation can be used as a signal of quality. That is to say that this affiliation increases the bargaining power of buyers to reduce the acquisition premium for targets. The findings are particularly important for the managers of firms managing SWFs' investments, as they can negotiate better deals with the targets due to the managers' affiliation with the SWFs.
\end{abstract}

Keywords: Asymmetric information, signaling theory, sovereign wealth funds (SWFs), Generalized estimating equation, mergers and acquisitions.

JEL Classification: G30,G34,G38

\footnotetext{
* Lahore Business School, The University of Lahore, Lahore, Pakistan.

** Associate Professor, College of Business, Zayed University, PO Box 144534, Khalifa City, Abu Dhabi, UAE.

**** Assistant Professor, Faculty of Management Sciences, International Islamic University, Islamabad, Pakistan.

${ }_{* * * *}^{*}$ Assistant Professor, UCP Business School, University of Central Punjab, Lahore, Pakistan.
} 


\section{Introduction}

Entrepreneurs and venture capitalists use the initial public offerings (IPO) of successful firms as a strategy to exit from the market. This exit mechanism by backers of the private firms has been investigated extensively in the existing studies, both theoretically and empirically (Bayar \& Chemmanur, 2011; Cumming \& Binti Johan, 2008; DeTienne, McKelvie \& Chandler, 2015). Another market exit option that is also used by the firms is the post-IPO acquisition of target firms by the acquirers, where the latter has more assets and experience in the industry. These postIPO acquisitions of the target firms, however, have not been discussed much in the mainstream literature (Bayar \& Chemmanur, 2011; Sullivan \& Unite, 2001; Qi, Sutton \& Zheng, 2013; Zhao, Xiong \& Shen, 2018). Post-IPO acquisitions have been increasing over the last few years. For instance, the national venture capital association (NVCA) documents that the IPO driven M\&A deals in United States increased from 698 deals in 2010, to 769 in 2017. The value of IPO-exit deals increased from US $\$ 31.61$ billion in 2010, to US\$51.02 billion in 2017, showing a $61 \%$ increase in the value of M\&Aexit deals from 2010 to 2017. ${ }^{1}$ Outside the US, the Asia-Pacific region has also experienced a rapid increase of about $44 \%$ in IPO driven M\&As deals, over the period from 2012 to 2017, where the acquisition deals' value increased from US $\$ 80$ billion in 2012 to US $\$ 115$ billion in 2017.2 The major contributors of such a large increase in acquisition deals is the appearance of sovereign wealth funds (SWFs) 3 , as buyers, in these deals. For example, Temasek Holdings, the SWF in Singapore, claimed the region's biggest deal, with a US\$5.7 billion investment to acquire the Hong Kong-based beauty retailer, A.S. Watson Group. ${ }^{4}$

Generally, the target firms in post-IPO acquisition deals have a short track record, i.e., acquirers don't have sufficient information about the true potential of the target firms, as it is not easy to value these firms. In addition, acquirers lack trust in the facts and figures provided by these target companies. This is because, usually, these firms hide damaging information and aggregate the positive factors (Ragozzino \& Reuer, 2007). This information asymmetry hampers the valuation of targets, as acquirers

\footnotetext{
${ }^{1}$ https://nvca.org/download/54862/

${ }^{2}$ https://www.bain.com/insights/asia-pacific-private-equity-report-2018/

${ }^{3}$ The Sovereign wealth fund institute defined Sovereign wealth fund as "A sovereign wealth fund is state- owned investment fund or entity established from balance of payment surpluses, official foreign currency operations, the proceeds from privatizations, government transfer payments, fiscal surpluses, and/or receipts resulting from resource exports".

${ }^{4}$ https://www.bain.com/insights/asia-pacific-private-equity-report-2018/
} 
are unable to evaluate the company with incomplete information. This eventually leads to the discounting of offer price by acquirers, resulting in reduced realized gains for the target firms. To increase the gains from acquisition deals, target firms send signals to acquirers in order to provide the information about the true potential and quality of the target firms (Akerlof, 1970; Reuer, Tong \& Wu, 2012). The signaling theory of Spence and Michael (1974) suggests that reliance on quality signals increases the valuation and acquisition premium of targets due to the least discounting of offer price by the acquirers (Arikawa \& Imad'Eddine, 2010; Hsu, 2004; Nicholson, 2005; Qi et al., 2013; Wright et al., 2004).

The existing studies on signals and acquisition premium use different signals to explain the acquisition premium of the target firms. For instance, the exiting research strengthens the belief that the reputation of the firm's underwriter is an indication of the quality of the firm (Arikan \& Capron, 2010; Carter \& Manaster, 1990; Kirkulak \& Davis, 2005). Also, the backing of prominent venture capitalists signal a firm's higher credence (Cho \& Lee, 2013; Ivanov \& Xie, 2010; Megginson \& Weiss, 1991). Furthermore, a positive affiliation with renowned alliance partners signifies the future prospects and probability of an increase in the firms' resources (Jensen, 2004). The other signals include the geographic location, IPO underpricing, government involvement, and the macro-economic effects (Choi, Petra \& Guar, 2015; Graebner \& Eisenhardt, 2004; Hayward \& Hambrick, 1997; Reuer et al., 2012; Rubbaniy, Shahzad \& Zahir-ul-Hassan, 2018). However, the sovereign wealth funds (SWFs) affiliation, as the signal of acquisition premium, has been a void in the existing literature, though some studies investigated the role of SWF investments in M\&A deals (Bortolotti, Fotak \& Megginson, 2015; Boubakri, Cosset \& Grira, 2016, 2017; Boubakri, Samir \& Cosset, 2011; Debarsy, Gnabo \& Kerkour, 2017; Lenihan, 2014). Despite a considerable amount of extant literature on the concept of acquisition premium (Certo, Holcomb \& Holmes, 2009; Higgins \& Gulati, 2003; Rubbaniy et al., 2018), little attention has been paid to the signaling effect of SWFs affiliation in the context of target firms. We seek to investigate the impact of the buy-side SWF affiliation on the acquisition premium of the target firms, specifically in the Asia-Pacific region. In particular, we aim to seek an answer to whether the buy-side SWFs affiliation explain acquisition premium of target firms in Asia-Pacific region.

The choice of Asia-Pacific region is motivated by a few defining factors. First, Asia-Pacific has become one of the foremost play grounds for M\&A activities. Second, the nationalist governments invest heavily in the SWFs in the regions which are involved in M\&A transactions. For instance, 
the Peoples Republic of China (PRC) owns the second largest SWF, with assets of $\$ 941$ billion 5 ; Australia and Singapore also hold SWFs, which invest in the M\&A markets. Third, the M\&A markets in the region are distinct from those in other developed countries due to different market inefficiencies. These include, for instance, offer price mechanism, low disclosure and investor protection (Chang, Chen, Chi \& Young, 2008).

We contribute to the existing literature in a few significant ways. First, we extend the exiting literature (see for instance Vasudeva, Nachum and Say (2017)) by linking the SWF affiliation with the acquisition premium of target firms. Second, we use the Generalized Estimation Equation (GEE) to deal with correlated outcomes resulting from the acquirers' involvement in multiple deals. Finally, we investigate the buyside SWFs' affiliation, as a signal of acquisition premium in the Asia-Pacific at regional, country, and sectoral level, which has never been examined in the exiting literature.

Our results show that the buy-side SWF's affiliation adversely, and significantly affects the acquisition premium in North Asia region. Our cross-country analysis shows a significantly negative effect of buy-side SWF's affiliation on the acquisition premium in China. The findings of our sectoral analysis report a significantly negative effect of SWF's affiliation on the acquisition premium in the energy and cyclical goods sector. The stronger effect in these sectors suggests that SWFs are likely to be more influential in M\&As deals conducted in strategic sectors. Our findings advocate that the buy-side SWF's affiliation can be used as the signal of quality by buyers (acquirers). This is because this particular affiliation increases the bargaining power of buyers, resulting in reduced acquisition premium for targets. The findings of this study are particularly important for the managers of firms which are actively involved in SWFs' investments. The main reason of this being that it provides empirical evidence on the bargaining power of acquirers, backed by SWFs, to curb the acquisition premiums of target firms.

The remainder of this paper is as follows. Section 2 outlines the data collection and methodology; Section 3 explains empirical results, and finally Section 4 concludes the study.

\footnotetext{
${ }^{5}$ https://www.swfinstitute.org/sovereign-wealth-fund-rankings/
} 


\section{Data Collection and Research Methodology}

\subsection{Data Collection}

The sample data of acquisition deals of different sectors and countries in Asia-Pacific region ${ }^{6}$ has been collected from the Thomson Reuters Eikon database, using a deals screener. Underwriter prominence (URP) is the ranking of the acquirer's underwriter, that is composed using the Loughran and Ritter (2004) ranking from 1980-2014. Our sample constitutes of the acquisition deals announced from January 2000 till December 2017, in the Asia-Pacific region. We applied certain filters on our data to keep it comparable with the existing literature. First, following the existing studies, we have excluded the financial sector firms, close ended mutual funds, real estate investment trusts (REITs), spin-offs and leveraged buyouts. Second, we included all the deals with non-missing values of our dependent variable acquisition premium. Third, we excluded the duplicate acquisition deals. Finally, we included the acquisition deals in which the acquirers acquired $51 \%$, or more stakes in the target firms after acquisition transaction. The above exclusions reduced our final sample to 1348 deals. To remove the biasness due to extreme values, and to normalize the data, we applied some additional filters. For instance, we winsorized different variables in the following ways: in acquisition premium (ACQP), we removed 28 observations based on the lowest (percentile 1\%) and highest percentiles (percentile 99\%); in IPO underpricing (IPOUND), we removed 138 observations (Percentile 1\% and Percentile 99\%), and after these exclusions our final sample includes 1182 observations.

Table 1 presents the descriptive statistics of our sample data, which includes the mean, standard deviation, skewness and kurtosis, providing information about the characteristics of the data. Table 1 also shows an average acquisition premium of $25.85 \%$, with a standard deviation of $33.85 \%$ that shows the deviation of the acquisition premiums received by target firms around its mean. The distribution of the acquisition premium is positively skewed, with a skewness value of 0.89 , and kurtosis of 6.19 . This shows leptokurtic behavior of the acquisition premium's data distribution. Our main explanatory variable, the buy-side SWF affiliation dummy variable (BSWF), is on average 0.02 with a standard deviation of 0.13 , but high values of kurtosis (60.23) and skewness (7.79). These values are not surprising as most of the acquirers are not affiliated with SWFs.

\footnotetext{
${ }^{6}$ List of countries and sectors is displayed in Appendix A.
} 
Furthermore, we also explained the descriptive statistics of control variables in Table 1.

Table 1: Descriptive Statistics

\begin{tabular}{lccccc}
\hline Variables & Obs. & Mean & $\begin{array}{c}\text { Standard } \\
\text { Deviation }\end{array}$ & Skewness & Kurtosis \\
\hline ACQP & 1182 & 25.85 & 33.85 & 0.89 & 6.19 \\
BSWF & 1182 & 0.02 & 0.13 & 7.7 & 60.23 \\
IPOUND & 1182 & 2.71 & 24.62 & -2.52 & 13.55 \\
URP & 1182 & 0.15 & 0.35 & 1.99 & 4.97 \\
VCI & 1182 & 0.13 & 0.34 & 2.17 & 5.73 \\
FSIZE & 1152 & 5.91 & 1.52 & 0.22 & 3.51 \\
DV & 1182 & 5.51 & 1.24 & 0.85 & 3.14 \\
TENDOF & 1182 & 0.09 & 0.28 & 2.95 & 9.68 \\
COMSTK & 1020 & 0.17 & 0.37 & 1.8 & 4.23 \\
CBORD & 1182 & 0.42 & 0.49 & 0.32 & 1.1 \\
SHARACQ & 1163 & 67.13 & 30.67 & -0.4 & 1.81 \\
\hline
\end{tabular}

In this table, our dependent variable is the Acquisition Premium \% (ACQP), which is the ratio of offer price to share price of target firms, 4 weeks before the acquisition announcement. Our independent variable is the buy-side sovereign wealth fund affiliation (BSWF), that is a dummy variable, which takes a value of ' 1 ' if sovereign wealth fund is affiliated with the acquirer, and otherwise ' 0 '. We have controlled other variables such as, IPO underpricing \% (IPOUND), that is the difference of initial offer price and target closing price on the day of the announcement (Loughran \& Ritter, 2004); Underwriter's Prestige (URP), that assumes a value of ' 1 ' if the target firm is affiliated with the leading underwriter, and ' 0 ' otherwise. Venture capitalist involvement (VCI) is a dummy variable that discloses the presence of the financial sponsors by assuming a value of ' 1 ', and ' 0 ' otherwise. Firm size \% (FSIZE) is the natural log of target total assets (\$mil). Deal value (DV) is the value of transaction (\$ mil) used to control for the size of the deal. Tender offer (TENDOF) is a dummy variable that shows tender offer status, as the target firm management resists to the tender offer initially to get a higher acquisition premium. The common stock (COMSTK) dummy variable is used to control for the payment method, as acquisition premiums fluctuate with the payment methods. Cross border (CBORD) dummy depicts whether the deal is between national boundaries or bidders from other countries are also involved in the transactions. The shares acquired \% (SHARACQ) indicates the percentage of shares acquired by the buyer in the acquisition deal. It is used to control the target's management demand for higher payments, should they lose control in the acquisition of the firm.

Source: Own composition from Thomson Reuters Eikon

\subsection{Theory and Hypothesis Development}

We begin with a discussion about the signaling theory by describing the role of different signals in determination of the acquisition premium. The next course of action would be to present how SWFs affiliation can be used as the signal of the acquisition premium of target firms. We conclude this section by explaining our contextual, methodological, and empirical extensions towards the signaling theory. 


\subsubsection{Signaling Theory of Market Signals:}

The signaling theory is presented by Spence and Michael (1974), which documents that information asymmetry exists in the markets, as one party may have more information than the other party in the underlying deals; this information asymmetry results in unsuccessful deals. The signaling theory is applied in situations where Party $A^{\prime} s$ (acquirer) decision is dependent on the other party, i.e., Party $B^{\prime} s$ (target) unknown characteristics. Consequently, the payoff of Party $B$ depends on Party $A$ 's decision. The signaling theory of Party $A^{\prime} s$ decision and Party $B^{\prime} s$ pay off depends upon the following assumptions: (i) the indirect interdependence of both parties $A$ and $B$ (Scitovsky, 1954) (ii) uncertainty about B's true characteristics before $A$ receives signals about $B$, (iii) rationality assumption of both parties, (iv) $B^{\prime}$ 's intentions to maximize its gains, and (v) $A^{\prime}$ 's intentions to correctly interpret the signals of Party $B$ (Park \& Patel, 2015). In addition, Party $A$ does not have the ability to change the conditions between the times at which the signals release, and the paying off to Party B (Hölmstrom, 1979).

The signaling theory is quite useful, and is applicable in diverse settings (Allen \& Faulhaber, 1989; Bergh, Connelly, Ketchen \& Shannon, 2014; Connelly, Certo, Ireland \& Reutzel, 2011; Park \& Patel, 2015). However, Spence (1978) specifically applied this theory in the job market, where a job applicant has sufficient information about his personality, but the employer does not have the complete information about the applicant. Due to credibility issues, the employers do not rely on what the applicants are saying during an interview, rather they rely on indirect (Kutsuna, Dimovski \& Brooks, 2008), costly and less imitable signals (Welch, 1989) of a job applicant's characteristics. These include the educational degrees of the applicant and other attributes. Rubbaniy et al. (2018) used IPO underpricing and sell-side government involvement as the signal of acquisition premium in Asia-Pacific region. They also found support in favor of the signaling effect of IPO underpricing in Asia-Pacific region, and in Singapore. Vasudeva et al. (2017) proposed the signaling characteristics of SWFs investments, and they suggest that SWFs can serve as intermediary signalers. The intermediary signalers point out towards the impact of unintentional signals, which happen to contrast with the deliberate, two-party signaling between a signaler and a receiver (Connelly et al., 2011; Janney \& Folta, 2003).

Existing literature documents some buy-side determinants of the acquisition premium. These include, for instance, how there are acquirer 
network ties with acquisition advisors (Beckman \& Haunschild, 2002), experience (Hayward \& Hambrick, 1997; Moeller \& Schlingemann, 2005), and management hubris. We extend the existing strand of literature by investigating the role of the third-party intermediary signaler. In our study involving M\&A deals, we use third-party intermediary signalers that signal about the quality of an entity of interest (e.g. firms). The signal receivers interpret the quality of the firms based on the intermediary's actions (e.g. SWF affiliation with acquirers). The credibility of third-party signaling is high, as the signaler does not intend to influence particular firms.

\subsection{Hypothesis}

We argue that like venture capitalist affiliation, alliances and underwriter prominence signals of acquisition premium, buy-side SWFs affiliation also reveals signalling information. Chari, Ouimet \& Tesar (2004) suggest that acquirers may have more bargaining power in emerging markets due to a smaller number of bidders competing for the target. This way acquirers can generate positive returns, as governments facilitate foreign acquisitions. Walkling and Edmister (1985) hypothesize that the acquisition premium of target firms depends on the relative bargaining power of the acquirer and the target firms. Billett and Ryngaert (1997) and Varaiya (1987) further explained that the distribution of the premium of bidders and targets depends on the relative bargaining strength of the target and acquirer firms.

Based on the discussion in the above literature, we expect that the affiliation of acquirers, with SWFs increases the bargaining power of the acquirers, which can reduce the acquisition premium of the target firms. These arguments lead us to develop the following hypothesis:

Hypothesis 1: Buy-side SWF's affiliation adversely affects the acquisition premium of target firms in M\&A deals.

\subsection{Empirical Model}

We have developed the following model for analysis of buy-side SWF affiliation as a signal of acquisition premiums in the Asia-Pacific region. Our model in Equation (1) investigates the impact of buy-side SWF affiliation on the acquisition premium of targets, in the presence of some standard control variables (Beckman \& Haunschild, 2002; Comment \& Schwert, 1995; Jarrell, Brickley \& Netter, 1988; Loughran \& Ritter, 2004). The model is defined in the following manner 


$$
\begin{gathered}
\text { ACQP }_{i, t}=\beta_{o}+\beta_{1} \text { BSWF }_{i}+\beta_{2} \text { IPOUND }_{i}+\beta_{3} \text { URP }_{i}+\beta_{4} \text { VCI }_{i}+ \\
\beta_{5} \text { FSIZE }_{i}+\beta_{6} \text { DV }_{i}+\beta_{7} \text { TENDOF }_{i}+\beta_{8} \text { COMSTK }_{i}+\beta_{9} \text { CBORD }_{i}+ \\
\beta_{10} \text { SHARACQ }_{i}+\mu_{i}
\end{gathered}
$$

Here, the dependent variable is the Acquisition Premium (ACQP) that is the ratio of offer price to share price of the target firm, 4 weeks before the acquisition announcement. Our independent variable is the buy-side SWF affiliation (BSWF) that signifies the dummy variables which indicates the value of ' 1 ', if SWF is affiliated with acquirer, and otherwise ' 0 '. IPO underpricing (IPOUND) is the percentage difference of the initial offer price, and the target closing price on the day of the announcement (Loughran \& Ritter, 2004). Underwriter Prestige (URP) is the dummy variable which takes a value of ' 1 ', if the target firm is affiliated with a leading underwriter, and ' 0 ' otherwise. Venture capitalist involvement (VCI) is the dummy variable that discloses the presence of the financial sponsors with a value of ' 1 ', otherwise ' 0 '. Firm size (FSIZE) is the natural log of total assets (\$mil) of the target, while Deal value (DV) is the value of transaction (\$mil), and is used to control for the size of the deal. Tender offer (TENDOF) is a dummy variable that shows the tender offer status. Usually, the target firm's management resists to the tender offer initially in order to increase the acquisition premium. Since, the acquisition premium fluctuates with the payment methods, we capture the payment method using the common stock (COMSTK) dummy variable, which takes a value of ' 1 ' if the acquirer issues stocks to buy target, and ' 0 ' otherwise. Cross border (CBORD) dummy depicts whether the deal is between the national boundaries, or if foreign bidders also take part in the transactions. The shares acquired (SHARACQ) display the percentage shared acquired during the acquisition deal. It is controlled because the management of the target firms requires higher payments if they lose control in the acquisition of the firm. Finally, $\mu$ represents the error term.

\subsection{Correlative Deals Problem}

In this study, we have improved the existing methodology by using the generalized estimating equations' approach, which is originally proposed by Liang and Zeger (1986). This is so because the GEE estimation solves the correlated outcomes of the same acquirer firms involved in various acquisitions over the different time periods. Specifically, the deals conducted by identical acquirers in our sample can be correlated due to their distinct characteristics, and expertise offered and available to the deal-making process. Furthermore, the QIC criterion is used to differentiate between the correlation structures (exchangeable and 
independent) in GEE estimations; the correlation structure with the smallest QIC value is the most optimal correlation structure for the estimation of the model.

\section{Empirical Results}

We begin our analysis by testing the existence of multicollinearity in our data, and Table 2 exhibits the pairwise correlation matrix between the variables of our study. Table 2 reports a negative correlation (-0.039) between the acquisition premium and the buy-side SWF affiliation. This reveals the view that the affiliation of the acquirer, with SWF is negatively associated with the acquisition premium of target firms. Moreover, the acquisition premiums are positively, and significantly related with IPO underpricing, with a correlation of 0.597 . The mean value of the variance inflation factor test is less than 5, which suggests an absence of the multicollinearity problem in our explanatory variables. Overall, our pairwise correlation matrix, and the variance inflation factor show that no perfect, or very high correlation exists in our explanatory, and control variables; therefore, it is safe to apply the econometric tests on our data. 
Table 2: Pairwise Correlation Matrix

\begin{tabular}{|c|c|c|c|c|c|c|c|c|c|c|c|}
\hline $\begin{array}{c}\text { Variab } \\
\text { les }\end{array}$ & ACQP & BSWF & $\begin{array}{c}\text { IPOU } \\
\text { ND }\end{array}$ & URP & VCI & FSIZE & DV & $\begin{array}{c}\text { TEND } \\
\text { OF }\end{array}$ & $\begin{array}{c}\text { COMS } \\
\text { TK }\end{array}$ & $\begin{array}{c}\text { CBOR } \\
\text { D } \\
\end{array}$ & $\begin{array}{c}\text { SHAR } \\
\text { ACQ }\end{array}$ \\
\hline$\overline{\mathrm{ACQP}}$ & 1.000 & & & & & & & & & & \\
\hline BSWF & -0.039 & 1.000 & & & & & & & & & \\
\hline IPOUN & $0.597^{*}$ & -0.006 & 1.000 & & & & & & & & \\
\hline D & & & & & & & & & & & \\
\hline URP & $0.069^{*}$ & 0.023 & 0.053 & 1.000 & & & & & & & \\
\hline VCI & 0.021 & 0.030 & 0.020 & 0.043 & 1.000 & & & & & & \\
\hline FSIZE & $\begin{array}{c}- \\
0.137^{*}\end{array}$ & $0.105^{*}$ & -0.012 & 0.053 & 0.018 & 1.000 & & & & & \\
\hline DV & -0.006 & $0.117^{*}$ & 0.039 & 0.056 & $0.080^{*}$ & $0.615^{*}$ & 1.000 & & & & \\
\hline $\begin{array}{l}\text { TEND } \\
\text { OF }\end{array}$ & 0.018 & 0.033 & $0.064^{*}$ & -0.000 & $-0.111^{*}$ & -0.044 & $-0.073^{*}$ & 1.000 & & & \\
\hline $\begin{array}{l}\text { COMST } \\
\mathrm{K}\end{array}$ & $\begin{array}{c}- \\
0.082^{*}\end{array}$ & $-0.061^{*}$ & $-0.067^{*}$ & -0.017 & $-0.119^{*}$ & $-0.094^{*}$ & 0.026 & $-0.141^{*}$ & 1.000 & & \\
\hline CBORD & $0.149^{*}$ & -0.027 & $0.115^{*}$ & 0.048 & $0.068^{*}$ & $-0.072^{*}$ & $0.064^{*}$ & $0.074^{*}$ & $-0.215^{*}$ & 1.000 & \\
\hline $\begin{array}{l}\text { SHARA } \\
\text { CQ }\end{array}$ & $0.185^{*}$ & -0.031 & $0.133^{*}$ & 0.002 & $0.059^{*}$ & $-0.288^{*}$ & $0.232^{*}$ & $-0.160^{*}$ & $0.276^{*}$ & $0.075^{*}$ & 1.000 \\
\hline VIF & 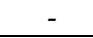 & 1.01 & 1.02 & 2.41 & 1.04 & 2.43 & 1.74 & 1.05 & 1.11 & 1.08 & 1.19 \\
\hline
\end{tabular}

In this table, our dependent variable is the Acquisition Premium \% (ACQP), which is the ratio of offer price to share price of target firms, 4 weeks before the acquisition announcement. Our independent variable is the buy-side sovereign wealth fund affiliation (BSWF), that is the dummy variable, which takes a value of ' 1 ' if sovereign wealth fund is affiliated with the acquirer and otherwise ' 0 '. We have controlled other variables such as, IPO underpricing \% (IPOUND), which is the difference of initial offer price and target closing price on the day of announcement (Loughran \& Ritter, 2004); Underwriter's Prestige (URP) that assumes a value of ' 1 ' if the target firm is affiliated with leading underwriter and ' 0 ' otherwise. Venture capitalist involvement (VCI) is a dummy variable that discloses the presence of the financial sponsors, by assuming a value of ' 1 ', and ' 0 ' otherwise. Firm size $\%$ (FSIZE) is the natural log of target total assets (\$mil). Deal value (DV) is the value of transaction (\$ mil) used to control for size of the deal. Tender offer (TENDOF) is a dummy variable that shows the tender offer status as the target firm management resists to the tender offer initially to get a higher acquisition premium. The common stock (COMSTK) dummy variable is used to control for the payment method, as the acquisition premiums fluctuate with the payment methods. Cross border (CBORD) dummy depicts whether the deal is between national boundaries or bidders from other countries are also involved in the transactions. The shares acquired \% (SHARACQ) indicates the percentage of shares acquired by the buyer in the acquisition deal. It is used to control target's management demand for higher payments, should they lose control in the acquisition of the firm. VIF explains the variance inflation factor test for the detection of multicollinearity.

Source: Own composition from Thomson Reuters Eikon

\subsection{Does Buy-Side SWFs' Affiliation Explain Acquisition Premium at Sub-Regional Level?}

To investigate the effects of buy-side SWF's affiliation, the results of Equation (1) are presented in Table 3. Column (1) to (5) of Table 3 show the results of Equation (1), for full sample acquisition deals, acquisition 
deals in North Asia, acquisition deals in South Asia, acquisition deals in Australasia, and acquisition deals conducted in South East Asia, respectively.

Our results show that in North Asia, the impact of buy-side SWF affiliation on acquisition premium is negative and significant at $1 \%$ level, with a coefficient of -46.406 , suggesting that buy-side SWF affiliation reduces the acquisition premium of target firms by $46.40 \%$. In other subregions, this effect is negative, but statistically insignificant. This negative effect of SWF affiliation on acquisition premium explains the bargaining power of acquirers. That is to say that, affiliation with financial intermediaries increases their power of negotiation in M\&A process, which is consistent with Chari et al. (2004), who suggest that acquirers may have more bargaining power in emerging markets due to a lesser number of bidders competing for the target.

The results of most of our control variables are consistent with the existing literature. For instance, IPO underpricing has a positive, and highly significant impact on the acquisition premium in all sub-regions, which is consistent with the beliefs of Reuer et al. (2012) and Rubbaniy et al. (2018); venture capitalists' involvement has a positively significant impact on the acquisition premium in North Asia, which is consistent with the results of Ragozzino and Blevins (2016); firm size has a negative and highly significant impact on the acquisition premium in full sample and South Asia, which is consistent with the findings of Park and Patel (2015); deal value displays a positive and significant impact on the acquisition premium in Southeast Asia, which is consistent with the revelations of Reuer et al. (2012); the common stock dummy variable reports a negative and statistically significant impact on acquisition premium in full sample, and in North Asia, which is consistent with the findings of Eckbo and Langohr (198), and Huang and Walkling (1987); cross border dummy shows a positive and significant impact in North Asia, i.e., the effect of quality signals are higher in cross border deals, which is consistent with the study results of Kang and Kim (2010) and Moeller and Schlingemann, (2005); the percentage of shares acquired in the M\&A transaction shows a positive and highly significant effect on the acquisition premium in full sample, and in North Asia, which is consistent with the results of Reuer et al. (2012). 


\section{Table 3: Sovereign Wealth Fund Affiliation as Signal of Acquisition Premium in Asia Pacific Region}

\begin{tabular}{lccccc}
\hline Variables & $\begin{array}{c}\mathbf{( 1 )} \\
\text { Full Sample }\end{array}$ & $\begin{array}{c}\mathbf{( 2 )} \\
\text { North Asia }\end{array}$ & $\begin{array}{c}\mathbf{( 3 )} \\
\text { South Asia }\end{array}$ & $\begin{array}{c}\mathbf{( 4 )} \\
\text { Australasia }\end{array}$ & $\begin{array}{c}(\mathbf{5 )} \\
\text { Southeast Asia }\end{array}$ \\
\hline BSWF & -8.354 & $-46.406^{* * *}$ & - & -16.370 & 0.035 \\
& $(6.621)$ & $(17.595)$ & - & $(17.608)$ & $(6.126)$ \\
IPOUND & $0.817^{* * *}$ & $0.789^{* * *}$ & $0.966^{* * *}$ & $0.748^{* * *}$ & $0.780^{* * *}$ \\
& $(0.038)$ & $(0.047)$ & $(0.181)$ & $(0.103)$ & $(0.077)$ \\
URP & 3.580 & $7.871^{* *}$ & -3.705 & 1.106 & -3.007 \\
& $(2.421)$ & $(3.775)$ & $(12.538)$ & $(4.672)$ & $(3.687)$ \\
VCI & -2.526 & $7.467^{*}$ & -7.687 & -8.335 & $-8.070^{* *}$ \\
& $(2.614)$ & $(3.915)$ & $(12.732)$ & $(5.704)$ & $(4.018)$ \\
FSIZE & $-2.171^{* *}$ & 1.006 & $-13.878^{* * *}$ & -1.528 & -2.204 \\
& $(0.886)$ & $(1.331)$ & $(4.601)$ & $(1.736)$ & $(1.712)$ \\
DV & 0.018 & -1.737 & 7.967 & -3.142 & $3.182^{*}$ \\
& $(1.054)$ & $(1.649)$ & $(4.914)$ & $(2.077)$ & $(1.848)$ \\
TENDOF & $-5.296^{*}$ & -2.124 & $-22.712^{* *}$ & -11.693 & -1.474 \\
& $(3.074)$ & $(4.873)$ & $(11.386)$ & $(8.597)$ & $(3.789)$ \\
COMSTK & $-7.063^{* * *}$ & $-8.055^{* *}$ & -15.105 & -6.425 & -4.397 \\
& $(2.512)$ & $(4.049)$ & $(13.086)$ & $(4.542)$ & $(5.116)$ \\
CBORD & 2.754 & $5.245^{*}$ & -4.714 & 1.866 & 0.554 \\
& $(1.824)$ & $(3.014)$ & $(8.708)$ & $(3.547)$ & $(2.831)$ \\
SHARACQ & $0.089^{* *}$ & $0.152^{* *}$ & -0.276 & 0.031 & -0.002 \\
& $(0.037)$ & $(0.061)$ & $(0.220)$ & $(0.089)$ & $(0.056)$ \\
Constant & $30.968^{* * *}$ & $12.431^{*}$ & $89.761^{* * *}$ & $56.802^{* * *}$ & $17.716^{* *}$ \\
& $(4.778)$ & $(7.367)$ & $(21.686)$ & $(10.762)$ & $(7.959)$ \\
Observations & 978 & 354 & 52 & 337 & 235 \\
Qic- & 700170 & 757318 & 892226 & 764523 & 749688 \\
Exchangeable & & & & & \\
Qic- & 700143 & 762162 & 888698 & 769203 & 748387 \\
Independent & & & & & \\
\hline & & & & & \\
\end{tabular}

In this table, our dependent variable is the Acquisition Premium \% (ACQP), which is the ratio of offer price to share price of the target firms, 4 weeks before the acquisition announcement. Our independent variable is the buy-side sovereign wealth fund affiliation (BSWF) that is a dummy variable, which takes a value ' 1 ' if sovereign wealth fund is affiliated with acquirer and otherwise ' 0 '. We have controlled other variables such as, IPO underpricing \% (IPOUND), which is the difference of initial offer price and target closing price on the day of announcement (Loughran \& Ritter, 2004); Underwriter's Prestige (URP) that assumes a value of ' 1 ' if the target firm is affiliated with leading underwriter, and ' 0 ' otherwise. Venture capitalist involvement (VCI) is a dummy variable that discloses the presence of the financial sponsors by assuming a value of ' 1 ', and ' 0 ' otherwise. Firm size \% (FSIZE) is the natural log of target total assets (\$mil). Deal value (DV) is the value of transaction (\$ mil) used to control for size of the deal. Tender offer (TENDOF) is a dummy variable that shows tender offer status as the target firm management resists to the tender offer initially to get a higher acquisition premium. The common stock (COMSTK) dummy variable is used to control for the payment method, as the acquisition premiums fluctuate with the payment methods. Cross border (CBORD) dummy depicts whether the deal is between national boundaries or bidders from other countries are also involved in the transactions. The shares acquired \% (SHARACQ) indicates percentage of shares acquired by the buyer in the acquisition deal. It is used to control the target's management demand for higher payments, should they lose control in the acquisition of the firm. ${ }^{*}, * *$, and ${ }^{* * *}$ indicate the statistical significance at the 10,5 and $1 \%$ levels of significance, respectively. QIC criterion is used to differentiate between the correlation structures in GEE estimations. The correlation structure with the smallest QIC value is the most optimal correlation structure for the estimation of the model. R-Square is not estimated because of the independent correlation among variables in GEE estimations. Standard errors are in parentheses. - indicates that the variable is not estimated.

Source: Own composition from Thomson Reuters Eikon 


\subsection{Does Buy-side SWFs' Affiliation Explain Acquisition Premium at Country Level?}

We suspect that the insignificant results for most of the regions in Table 3 may be due to the missing values of SWFs across different regions. Alternatively, the insignificant results could be due to the huge diversity across different countries of the Asia-Pacific region. We therefore investigate whether the buy-side SWF's affiliation's effect on the acquisition premium is country specific. To serve the purpose, we have run Equation (1) across 10 different countries ${ }^{7}$, and the results are posted in Table 4. Columns (1) to (10) of Table 4 show the results of Equation (1) for acquisition deals in Australia, New Zealand, China, South Korea, Taiwan, Hong Kong, India, Thailand, Malaysia and Singapore, respectively.

Table 4 shows that the effect of buy-side SWF affiliation on acquisition premium is negative and highly significant, only in China. The coefficient of SWF's affiliation for China has a value of -45.684, suggesting that buy-side SWF's affiliation reduces the acquisition premium of target firms by $45.68 \%$ in China. This negative effect of SWF affiliation on the acquisition premium in China is likely to be due to their nationalist governments (Greenfeld, 2012; Zheng, 1999; Zhimin 2005). This results in a strong affiliation of the acquirers with financial intermediaries, which increases their negotiation power in the M\&A deals process in turn. The results of our control variables are consistent with existing studies (Beckman \& Haunschild, 2002; Jarrell et al., 1988; Reuer et al., 2012).

\footnotetext{
${ }^{7}$ The data for analysis is run across 10 countries, while the data for the other sampled countries is not sufficient enough to run the analysis.
} 


\section{Table 4: Sovereign Wealth Fund Affiliation as Signal of Acquisition Premium in different Countries of Asia-Pacific Region}

\begin{tabular}{|c|c|c|c|c|c|c|c|c|c|c|}
\hline Variables & $\begin{array}{c}\text { (1) } \\
\text { Australia }\end{array}$ & $\begin{array}{c}\text { (2) } \\
\text { New } \\
\text { Zealand }\end{array}$ & $\begin{array}{l}\text { (3) } \\
\text { China }\end{array}$ & $\begin{array}{c}(4) \\
\text { South } \\
\text { Korea }\end{array}$ & $\begin{array}{c}\text { (5) } \\
\text { Taiwan }\end{array}$ & $\begin{array}{c}(6) \\
\text { Hong } \\
\text { Kong }\end{array}$ & $\begin{array}{l}(7) \\
\text { India }\end{array}$ & $\begin{array}{c}\text { (8) } \\
\text { Thailand }\end{array}$ & $\begin{array}{c}\text { (9) } \\
\text { Malaysia }\end{array}$ & $\begin{array}{c}\mathbf{( 1 0 )} \\
\text { Singapore }\end{array}$ \\
\hline BSWF & $\begin{array}{l}-18.771 \\
(17.352)\end{array}$ & $\begin{array}{l}- \\
-\end{array}$ & $\begin{array}{c}-45.684^{* *} \\
(17.765)\end{array}$ & - & - & - & - & $\begin{array}{c}-6.408 \\
(14.163)\end{array}$ & $\begin{array}{c}-9.381 \\
(11.030)\end{array}$ & $\begin{array}{c}4.205 \\
(7.666)\end{array}$ \\
\hline IPOUND & $\begin{array}{c}0.804^{* * *} \\
(0.103)\end{array}$ & $\begin{array}{c}-0.072 \\
(0.749)\end{array}$ & $\begin{array}{c}0.687^{* * *} \\
(0.070)\end{array}$ & $\begin{array}{c}0.465^{* * *} \\
(0.078)\end{array}$ & $\begin{array}{c}0.803^{* * *} \\
(0.110)\end{array}$ & $\begin{array}{c}0.915^{* * *} \\
(0.089)\end{array}$ & $\begin{array}{c}0.953^{* * *} \\
(0.186)\end{array}$ & $\begin{array}{c}1.522^{* * *} \\
(0.257)\end{array}$ & $\begin{array}{c}0.770^{* * *} \\
(0.140)\end{array}$ & $\begin{array}{c}0.673^{* * *} \\
(0.139)\end{array}$ \\
\hline URP & $\begin{array}{c}3.148 \\
(4.847)\end{array}$ & $\begin{array}{c}-9.202 \\
(20.156)\end{array}$ & $\begin{array}{l}11.373^{*} \\
(6.069)\end{array}$ & $\begin{array}{l}-4.862 \\
(8.888)\end{array}$ & $\begin{array}{l}-1.059 \\
(6.739)\end{array}$ & $\begin{array}{c}7.002 \\
(7.150)\end{array}$ & $\begin{array}{c}-4.324 \\
(12.701)\end{array}$ & - & $\begin{array}{l}-2.608 \\
(6.115)\end{array}$ & $\begin{array}{l}-3.547 \\
(5.548)\end{array}$ \\
\hline VCI & $\begin{array}{l}-7.208 \\
(5.673)\end{array}$ & $\begin{array}{l}-50.298^{* *} \\
(22.324)\end{array}$ & $\begin{array}{c}12.900^{* *} \\
(5.588)\end{array}$ & $\begin{array}{c}6.142 \\
(6.612)\end{array}$ & $\begin{array}{c}-6.118 \\
(12.640)\end{array}$ & $\begin{array}{c}0.462 \\
(8.660)\end{array}$ & $\begin{array}{c}-8.546 \\
(12.530)\end{array}$ & $\begin{array}{l}27.178^{* *} \\
(13.299)\end{array}$ & $\begin{array}{c}-16.684 \\
(11.223)\end{array}$ & $\begin{array}{l}-8.251^{*} \\
(4.524)\end{array}$ \\
\hline FSIZE & $\begin{array}{l}-2.255 \\
(1.740)\end{array}$ & $\begin{array}{c}9.180 \\
(10.541)\end{array}$ & $\begin{array}{c}1.314 \\
(2.282)\end{array}$ & $\begin{array}{l}-1.982 \\
(2.094)\end{array}$ & $\begin{array}{l}-0.302 \\
(3.262)\end{array}$ & $\begin{array}{c}2.740 \\
(2.549)\end{array}$ & $\begin{array}{c}-13.670^{* * *} \\
(4.675)\end{array}$ & $\begin{array}{l}-3.099 \\
(3.867)\end{array}$ & $\begin{array}{l}3.404 \\
(3.344)\end{array}$ & $\begin{array}{c}-7.772^{* * *} \\
(2.295)\end{array}$ \\
\hline DV & $\begin{array}{l}-1.875 \\
(2.077)\end{array}$ & $\begin{array}{l}-18.602 \\
(15.936)\end{array}$ & $\begin{array}{l}-2.409 \\
(2.655)\end{array}$ & $\begin{array}{l}-0.594 \\
(2.354)\end{array}$ & $\begin{array}{l}-3.054 \\
(3.184)\end{array}$ & $\begin{array}{l}-0.057 \\
(3.441)\end{array}$ & $\begin{array}{c}7.675 \\
(5.037)\end{array}$ & $\begin{array}{l}-1.206 \\
(4.697)\end{array}$ & $\begin{array}{l}-5.878 \\
(3.872)\end{array}$ & $\begin{array}{c}10.702^{* * *} \\
(2.534)\end{array}$ \\
\hline TENDOF & $\begin{array}{c}-15.596^{*} \\
(9.283)\end{array}$ & $\begin{array}{c}-8.972 \\
(29.983)\end{array}$ & $\begin{array}{c}13.294 \\
(13.402)\end{array}$ & $\begin{array}{l}-1.808 \\
(6.457)\end{array}$ & $\begin{array}{l}-4.340 \\
(6.843)\end{array}$ & $\begin{array}{l}-13.411 \\
(9.190)\end{array}$ & $\begin{array}{c}-22.135^{* *} \\
(11.195)\end{array}$ & $\begin{array}{c}-14.419^{*} \\
(7.599)\end{array}$ & $\begin{array}{l}-1.168 \\
(8.513)\end{array}$ & $\begin{array}{l}-2.268 \\
(5.029)\end{array}$ \\
\hline COMSTK & $\begin{array}{l}-7.075 \\
(4.491)\end{array}$ & $\begin{array}{c}-3.137 \\
(28.762)\end{array}$ & $\begin{array}{l}21.992 * * \\
(10.105)\end{array}$ & $\begin{array}{c}-13.214^{* * *} \\
(4.787)\end{array}$ & $\begin{array}{l}-5.850 \\
(6.722)\end{array}$ & $\begin{array}{l}-24.507^{*} \\
(13.097)\end{array}$ & $\begin{array}{c}-15.322 \\
(12.778)\end{array}$ & $\begin{array}{c}-16.991^{*} \\
(9.679)\end{array}$ & $\begin{array}{l}-3.774 \\
(9.743)\end{array}$ & $\begin{array}{l}9.411 \\
(8.660)\end{array}$ \\
\hline CBORD & $\begin{array}{l}-0.959 \\
(3.563)\end{array}$ & $\begin{array}{l}37.369^{* *} \\
(17.836)\end{array}$ & $\begin{array}{c}1.592 \\
(5.216)\end{array}$ & $\begin{array}{l}11.689^{*} \\
(6.154)\end{array}$ & $\begin{array}{c}3.966 \\
(7.533)\end{array}$ & $\begin{array}{c}2.959 \\
(5.186)\end{array}$ & $\begin{array}{l}-4.785 \\
(7.691)\end{array}$ & $\begin{array}{c}9.663 \\
(9.024)\end{array}$ & $\begin{array}{l}-4.420 \\
(6.005)\end{array}$ & $\begin{array}{c}0.563 \\
(3.684)\end{array}$ \\
\hline SHARACQ & $\begin{array}{l}-0.041 \\
(0.095)\end{array}$ & $\begin{array}{c}0.341 \\
(0.294)\end{array}$ & $\begin{array}{c}0.114 \\
(0.094)\end{array}$ & $\begin{array}{c}0.050 \\
(0.084)\end{array}$ & $\begin{array}{c}0.095 \\
(0.137)\end{array}$ & $\begin{array}{c}0.389^{* * *} \\
(0.131)\end{array}$ & $\begin{array}{l}-0.263 \\
(0.231)\end{array}$ & $\begin{array}{c}0.214 \\
(0.172)\end{array}$ & $\begin{array}{c}0.192 \\
(0.120)\end{array}$ & $\begin{array}{l}-0.100 \\
(0.072)\end{array}$ \\
\hline Constant & $\begin{array}{c}61.181^{* * *} \\
(11.101)\end{array}$ & $\begin{array}{l}45.804 \\
(54.986)\end{array}$ & $\begin{array}{c}12.262 \\
(12.761)\end{array}$ & $\begin{array}{c}32.375^{* * *} \\
(10.164)\end{array}$ & $\begin{array}{c}27.282 \\
(18.258)\end{array}$ & $\begin{array}{l}-11.550 \\
(13.803)\end{array}$ & $\begin{array}{c}89.533^{* * *} \\
(20.380)\end{array}$ & $\begin{array}{l}28.652^{* *} \\
(13.707)\end{array}$ & $\begin{array}{c}21.916 \\
(15.667)\end{array}$ & $\begin{array}{l}18.256^{*} \\
(10.769)\end{array}$ \\
\hline Observations & 317 & 20 & 143 & 41 & 52 & 118 & 51 & 21 & 74 & 119 \\
\hline $\begin{array}{l}\text { Qic- } \\
\text { Exchangeable }\end{array}$ & 785823 & 1770089 & 890082 & 813256 & 806195 & 868859 & 884621 & 1170299 & - & 843982 \\
\hline $\begin{array}{l}\text { Qic- } \\
\text { Independent }\end{array}$ & 796838 & 1702771 & 901323 & 813144 & 804059 & 867193 & 886685 & 1161123 & 837525 & 843928 \\
\hline
\end{tabular}

In this table, our dependent variable is the Acquisition Premium \% (ACQP), which is the ratio of offer price to share price of target firms, 4 weeks before the acquisition announcement. Our independent variable is the buy-side sovereign wealth fund affiliation (BSWF) that is the dummy variable, which takes a value of ' 1 ' if sovereign wealth fund is affiliated with the acquirer, and otherwise ' 0 '. We have controlled other variables such as, IPO underpricing \% (IPOUND), which is the difference of initial offer price and target closing price on the day of the announcement (Loughran \& Ritter, 2004); Underwriter's Prestige (URP) that assumes a value of ' 1 ' if target firm is affiliated with leading underwriter, and ' 0 ' otherwise. Venture capitalist involvement (VCI) is a dummy variable that discloses the presence of the financial sponsors by assuming a value of ' 1 ', and ' 0 ' otherwise. Firm size $\%$ (FSIZE) is the natural log of target total assets (\$mil). Deal value (DV) is the value of transaction (\$ mil) used to control for the size of the deal. Tender offer (TENDOF) is a dummy variable that shows tender offer status as the target firm management resists to the tender offer initially to get a higher acquisition premium. The common stock (COMSTK) dummy variable is used to control for the payment method as acquisition premiums fluctuate with the payment methods. Cross border (CBORD) dummy depicts whether the deal is between national boundaries or bidders from other countries are also involved in the transactions. The shares acquired \% (SHARACQ) indicates the percentage of shares acquired by the buyer in the acquisition deal. It is used to control the target's management demand for higher payments should they lose control in the acquisition of the firm. ${ }^{*}, * *$, and ${ }^{* * *}$ indicate the statistical significance at the 10,5 and $1 \%$ levels of significance, respectively. QIC criterion is used to differentiate between the correlation structures in GEE estimations, the correlation structure with the smallest QIC value is the most optimal correlation structure for the estimation of the model. R-Square is not estimated because of the independent correlation among variables in GEE estimations. Standard errors are in parentheses. - indicates that the variable is not estimated.

Source: Own composition from Thomson Reuters Eikon 


\subsection{Does Buy-side SWFs' Affiliation Explain Acquisition Premium at Sectoral Level?}

The insignificant effect of the buy-side SWF's affiliation, on the acquisition premium in four out of five countries stir us to investigate whether the insignificance is driven by the M\&A heterogeneity across different sectors of the economy. This is because some sectors are strategically more important than the others; and thus, the buy-side SWF's affiliation effect may vary across different sectors of the economy. We therefore investigate whether the buy-side SWF's affiliation effect on acquisition premium is sector specific. To investigate this effect, we rerun Equation (1) across 8 different sectors of the economy, and the results are posted in Table 5. Columns (1) to (8) of Table 5 show the results of Equation (1) for acquisition deals in energy, cyclical goods, technology, utilities, basic material, non-cyclical goods, telecommunications and healthcare sectors, respectively.

The results in Column (1) and (2) of Table 5 show that the SWF's affiliation has a significantly negative effect on the acquisition premium in energy and cyclical goods sectors at a $1 \%$ level of significance.

This negative effect of SWF affiliation on acquisition premium in these sectors is due to their strategic nature, i.e., the energy sector's revenue is a major source of sovereign wealth funds (Boubakri et al., 2011; Kotter \& Lel, 2011; Truman, 2009), and cyclical goods includes heavy machinery and raw materials that increase their power of negotiation in M\&A deals process in these sectors. 


\section{Table 5: Sovereign Wealth Fund Affiliation as Signal of Acquisition Premium in Asia-Pacific Region- Sectoral Analysis}

\begin{tabular}{|c|c|c|c|c|c|c|c|c|}
\hline & (1) & $(2)$ & (3) & (4) & (5) & (6) & (7) & (8) \\
\hline Variables & Energy & $\begin{array}{c}\text { Cyclical } \\
\text { Goods }\end{array}$ & $\begin{array}{c}\text { Techno- } \\
\text { logy }\end{array}$ & Utilities & $\begin{array}{c}\text { Basic } \\
\text { Materials }\end{array}$ & $\begin{array}{c}\text { Non-Cyclical } \\
\text { Goods }\end{array}$ & $\begin{array}{l}\text { Telecommun- } \\
\text { ications }\end{array}$ & $\begin{array}{c}\text { Health- } \\
\text { care }\end{array}$ \\
\hline \multirow[t]{2}{*}{$\overline{\text { BSWF }}$} & $-104.978^{* * *}$ & $-35.369^{*}$ & 12.951 & - & - & - & -18.778 & -24.325 \\
\hline & (34.035) & (18.189) & (12.257) & - & - & - & (12.349) & $(20.470)$ \\
\hline \multirow[t]{2}{*}{ IPOUND } & $0.807^{* * *}$ & $0.846^{* * *}$ & $0.872^{* * *}$ & $0.504^{* * *}$ & $0.983^{* * *}$ & $0.758^{* * *}$ & $0.384^{* * *}$ & $0.759^{* * *}$ \\
\hline & $(0.204)$ & $(0.087)$ & (0.108) & $(0.129)$ & $(0.116)$ & $(0.083)$ & $(0.101)$ & $(0.129)$ \\
\hline \multirow[t]{2}{*}{ URP } & -0.201 & 1.225 & -3.804 & -5.035 & 6.305 & -3.354 & $12.354^{* *}$ & -3.123 \\
\hline & (8.799) & $(5.562)$ & (5.618) & (7.757) & (6.671) & (5.788) & (5.170) & $(11.400)$ \\
\hline \multirow[t]{2}{*}{ VCI } & $-26.643^{*}$ & 1.685 & $14.372^{* * *}$ & 5.890 & -13.367 & $-11.287^{*}$ & -10.204 & -4.174 \\
\hline & (14.632) & (5.017) & (5.432) & (6.319) & (12.363) & (5.963) & (8.597) & $(9.478)$ \\
\hline \multirow[t]{2}{*}{ FSIZE } & $-14.889^{* * *}$ & -2.214 & -2.206 & -0.685 & -3.063 & 0.068 & -1.715 & -2.890 \\
\hline & $(3.645)$ & $(2.220)$ & (2.500) & (2.683) & (2.029) & (2.544) & (3.511) & $(4.053)$ \\
\hline \multirow[t]{2}{*}{ DV } & $8.711^{* *}$ & 1.617 & 1.882 & -3.369 & -0.497 & -0.689 & -1.453 & 1.017 \\
\hline & $(4.164)$ & (2.440) & (2.843) & (3.217) & (2.652) & (2.601) & $(4.620)$ & $(5.053)$ \\
\hline \multirow[t]{2}{*}{ TENDOF } & -12.888 & -9.683 & -9.932 & 4.071 & -0.072 & 3.600 & -0.710 & -24.278 \\
\hline & (14.948) & $(7.846)$ & (6.717) & (7.817) & (10.010) & (7.709) & (7.792) & (15.237) \\
\hline \multirow[t]{2}{*}{ COMSTK } & $-20.222^{* *}$ & 3.872 & $-9.873^{*}$ & -7.358 & $-12.409^{* *}$ & $-13.998^{*}$ & $-18.491^{* * *}$ & -10.791 \\
\hline & $(8.262)$ & (6.955) & (5.686) & $(10.869)$ & (5.435) & $(7.401)$ & (6.921) & (11.259) \\
\hline \multirow[t]{2}{*}{ CBORD } & -4.221 & 5.521 & 2.305 & $13.029^{* * *}$ & -6.743 & 4.853 & -1.461 & 10.770 \\
\hline & (7.219) & (4.169) & $(4.707)$ & (4.945) & (4.614) & $(4.317)$ & (6.554) & (7.041) \\
\hline \multirow[t]{2}{*}{ SHARACQ } & -0.178 & 0.075 & 0.099 & 0.164 & $0.197^{*}$ & 0.104 & $0.392^{* * *}$ & -0.250 \\
\hline & (0.173) & $(0.082)$ & (0.089) & (0.114) & (0.103) & $(0.090)$ & $(0.135)$ & (0.156) \\
\hline \multirow[t]{2}{*}{ Constant } & $90.300^{* * *}$ & $18.972^{*}$ & 17.756 & 22.639 & $37.756^{* * *}$ & 15.591 & $25.515^{*}$ & $56.373^{* * *}$ \\
\hline & (19.732) & (11.247) & (12.703) & (14.303) & $(12.306)$ & (10.860) & (13.926) & $(20.227)$ \\
\hline $\begin{array}{l}\text { Observa- } \\
\text { tions }\end{array}$ & 69 & 188 & 137 & 22 & 161 & 91 & 21 & 67 \\
\hline $\begin{array}{l}\text { Qic- } \\
\text { Exchange- } \\
\text { able }\end{array}$ & 1108849 & 740573 & 765767 & 881820 & 764254 & - & - & 838851 \\
\hline $\begin{array}{l}\text { Qic- } \\
\text { Independ- } \\
\text { ent }\end{array}$ & 1107766 & 742267 & 764912 & 888505 & 764103 & 786121 & 877037 & 839209 \\
\hline
\end{tabular}

In this table, our dependent variable is the Acquisition Premium \% (ACQP), which is the ratio of offer price to share price of target firms, 4 weeks before the acquisition announcement. Our independent variable is the buyside sovereign wealth fund affiliation (BSWF), that is the dummy variable, which takes a value of ' 1 ' if sovereign wealth fund is affiliated with an acquirer, and otherwise ' 0 '. We have controlled other variables such as, IPO underpricing \% (IPOUND) which is the difference of initial offer price and target closing price on the day of the announcement (Loughran \& Ritter, 2004); Underwriter's Prestige (URP) that assumes a value of ' 1 ', if the target firm is affiliated with leading underwriter, and ' 0 ' otherwise. Venture capitalist involvement (VCI) is a dummy variable that discloses the presence of the financial sponsors by assuming a value of ' 1 ', and ' 0 ' otherwise. Firm size \% (FSIZE) is the natural log of target total assets (\$mil). Deal value (DV) is the value of transaction (\$ mil) used to control for the size of the deal. Tender offer (TENDOF) is a dummy variable that shows tender offer status as the target firm management resists to the tender offer initially to get a higher acquisition premium. The common stock (COMSTK) dummy variable is used to control for the payment method, as the acquisition premiums fluctuate with the payment methods. Cross border (CBORD) dummy depicts whether the deal is between national boundaries or bidders from other countries are also involved in the transactions. The shares acquired \% (SHARACQ) indicates the percentage of shares acquired by the buyer in the acquisition deal. It is used to control the target's management demand for higher payments, should they lose control in the acquisition of the firm. ${ }^{*},{ }^{* *}$, and ${ }^{* * *}$ indicate the statistical significance at the 10,5 and $1 \%$ levels of significance, respectively. The QIC criterion is used to differentiate between the correlation structures in GEE estimations, the correlation structure with the smallest QIC value is the most optimal correlation structure for the estimation of the model. The R-Square is not estimated because of the independent correlation among variables in GEE estimations. Standard errors are in parentheses. - indicate that the variable is not estimated.

Source: Own composition from Thomson Reuters Eikon 


\section{Conclusions}

Although Vasudeva et al. (2017) investigated the signaling effect of SWFs' investments in determination of firm ownership choice in foreign acquisition deals, the buy-side SWFs' affiliation as the signal of acquisition premium is a void in the existing studies as per the knowledge of the authors. This study attempts to fill this very gap, and extends the exiting literature on signaling theory by offering the role of buy-side SWF's affiliation in order to explain the acquisition premium of target firms.

Our results support the theory that buy-side SWF's affiliation reduces the acquisition premium of target firms significantly in the North Asia region. In other sub-regions, this effect is negative but statistically insignificant. These findings are consistent with the theory that the negative effect of SWF's affiliation on acquisition premium is due to the higher bargaining power of acquirers. This means that the affiliation with financial intermediaries increases the acquirer's power of negotiation in the M\&A process.

Our cross-country analysis shows a negatively significant effect of buy-side SWF's affiliation, on the acquisition premium only in China. The findings of our sectoral analysis report an adversely significant effect of SWF's affiliation on the acquisition premium in the energy and cyclical goods sector. A significantly negative effect of SWF's affiliation on the acquisition premium in these sectors suggests that the SWFs are likely to be more influential in the M\&As deals conducted in these strategic sectors. Overall, our findings suggest that the buy-side SWF's affiliation can be used as a signal of buyer's quality, as this affiliation increases the bargaining power of buyers resulting in reduced acquisition premium for targets in certain regions, countries and sectors.

The findings of this study are particularly important for the managers of SWFs who invest in M\&A deals in South Asia, China, and other strategic sectors. It is believed that the main goal of the managers is to maximize the value of the shareholders, in our case, this is the value of SWF. Hence, our empirical evidence, that SWF's affiliation provides a relative reduction in the acquisition premium to the targets or financing cost of the buyers, makes investment managers of SWFs more confident, while bargaining the M\&A deals with the targets. The most striking result that emerged from our analysis is that the effect of SWF's affiliation is strong in the energy sector deals, as most of the sovereign wealth funds are in oil exporting countries and have major stakes in the energy sector's M\&A activities and investments (Kotter \& Lel, 2011; Truman, 2009). 


\section{References}

Akerlof, G. A. (1970). The market for" lemons": Quality uncertainty and the market mechanism. The Quarterly Journal of Economics, 84(3), 488-500.

Allen, F., \& Faulhaber, G. R. (1989). Signalling by underpricing in the IPO market. Journal of Financial Economics, 23(2), 303-323.

Arikan, A. M., \& Capron, L. (2010). Do newly public acquirers benefit or suffer from their pre-IPO affiliations with underwriters and VCs?. Strategic Management Journal, 31(12), 1257-1289.

Arikawa, Y., \& Imad'Eddine, G. (2010). Venture capital affiliation with underwriters and the underpricing of initial public offerings in Japan. Journal of Economics and Business, 62(6), 502-516.

Bayar, O., \& Chemmanur, T. J. (2011). IPOs versus acquisitions and the valuation premium puzzle: A theory of exit choice by entrepreneurs and venture capitalists. Journal of Financial and Quantitative Analysis, 46(6), 1755-1793.

Beckman, C. M., \& Haunschild, P. R. (2002). Network learning: The effects of partners' heterogeneity of experience on corporate acquisitions. Administrative Science Quarterly, 47(1), 92-124.

Bergh, D. D., Connelly, B. L., Ketchen, D. J., \& Shannon, L. M. (2014). Signalling theory and equilibrium in strategic management research: An assessment and a research agenda. Journal of Management Studies, 51(8), 1334-1360.

Billett, M. T., \& Ryngaert, M. (1997). Capital structure, asset structure and equity takeover premiums in cash tender offers. Journal of Corporate Finance, 3(2), 141-165.

Bortolotti, B., Fotak, V., \& Megginson, W. L. (2015). The sovereign wealth fund discount: Evidence from public equity investments. The Review of Financial Studies, 28(11), 2993-3035.

Boubakri, N., Cosset, J.-C., \& Grira, J. (2016). Sovereign wealth funds targets selection: A comparison with pension funds. Journal of International Financial Markets, Institutions and Money, 42 (May), 60-76. 
Boubakri, N., Cosset, J.-C., \& Grira, J. (2017). Sovereign wealth funds investment effects on target firms' competitors. Emerging Markets Review, 30 (March), 96-112.

Boubakri, N., Samir, N., \& Cosset, J.-C. (2011). Sovereign Wealth Fund Acquisitions: A Comparative Analysis with Mutual Funds. In Boubakri, N. and Cosset, J. (Ed.), Institutional Investors in Global Capital Markets (pp. 355-389): Bradford, England: Emerald Group.

Carter, R., \& Manaster, S. (1990). Initial public offerings and underwriter reputation. The Journal of Finance, 45(4), 1045-1067.

Certo, S. T., Holcomb, T. R., \& Holmes, R. M. (2009). IPO research in management and entrepreneurship: Moving the agenda forward. Journal of Management, 35(6), 1340-1378.

Chang, E., Chen, C., Chi, J., \& Young, M. (2008). IPO underpricing in China: New evidence from the primary and secondary markets. Emerging Markets Review, 9(1), 1-16.

Chari, A., Ouimet, P. P., \& Tesar, L. L. (2004, March). Cross border mergers and acquisitions in emerging markets: The stock market valuation of corporate control. Paper presented at the EFA 2004 Maastricht Meeting Paper (No. 3479).

Cho, J., \& Lee, J. (2013). The venture capital certification role in R\&D: Evidence from IPO underpricing in Korea. Pacific-Basin Finance Journal, 23, 83-108.

Choi, G., Petra, C., \& Guar, A. (2015 ,January). Target CSR as a Signal in Acquisitions: Its Effect on Acquisition Premium, (1), 17621. Paper presented at the Academy of Management Proceedings, Briarcliff Manor, New York, United States of America

Comment, R., \& Schwert, G. W. (1995). Poison or placebo? Evidence on the deterrence and wealth effects of modern antitakeover measures. Journal of Financial Economics, 39(1), 3-43.

Connelly, B. L., Certo, S. T., Ireland, R. D., \& Reutzel, C. R. (2011). Signaling theory: A review and assessment. Journal of Management, 37(1), 39-67.

Cumming, D., \& binti Johan, S. A. (2008). Preplanned exit strategies in venture capital. European Economic Review, 52(7), 1209-1241. 
Debarsy, N., Gnabo, J.-Y., \& Kerkour, M. (2017). Sovereign wealth funds' cross-border investments: Assessing the role of country-level drivers and spatial competition. Journal of International Money and Finance, 76, 68-87.

DeTienne, D. R., McKelvie, A., \& Chandler, G. N. (2015). Making sense of entrepreneurial exit strategies: A typology and test. Journal of Business Venturing, 30(2), 255-272.

Eckbo, B. E., \& Langohr, H. (1989). Information disclosure, method of payment, and takeover premiums: Public and private tender offers in France. Journal of Financial Economics, 24(2), 363-403.

Graebner, M. E., \& Eisenhardt, K. M. (2004). The seller's side of the story: Acquisition as courtship and governance as syndicate in entrepreneurial firms. Administrative Science Quarterly, 49(3), 366-403.

Greenfeld, L. (2012). Nationalism. in the Wiley-Blackwell Encyclopedia of Globalization, G. Ritzer (Ed.). doi:10.1002/9780470670590.wbeog415

Hayward, M. L., \& Hambrick, D. C. (1997). Explaining the premiums paid for large acquisitions: Evidence of CEO hubris. Administrative Science Quarterly, 12(1) 103-127.

Higgins, M. C., \& Gulati, R. (2003). Getting off to a good start: The effects of upper echelon affiliations on underwriter prestige. Organization Science, 14(3), 244-263.

Hölmstrom, B. (1979). Moral Hazard and Observability. The Bell Journal of Economics, 10(1), 74-91.

Hsu, D. H. (2004). What do entrepreneurs pay for venture capital affiliation? The Journal of Finance, 59(4), 1805-1844.

Huang, Y.-S., \& Walkling, R. A. (1987). Target abnormal returns associated with acquisition announcements: Payment, acquisition form, and managerial resistance. Journal of Financial Economics, 19(2), 329-349.

Ivanov, V. I., \& Xie, F. (2010). Do corporate venture capitalists add value to start-up firms? Evidence from IPOs and acquisitions of VC-backed companies. Financial Management, 39(1), 129-152. 
Janney, J. J., \& Folta, T. B. (2003). Signaling through private equity placements and its impact on the valuation of biotechnology firms. Journal of Business Venturing, 18(3), 361-380.

Jarrell, G. A., Brickley, J. A., \& Netter, J. M. (1988). The market for corporate control: The empirical evidence since 1980. Journal of Economic Perspectives, 2(1), 49-68.

Jensen, M. (2004). Who gets Wall Street's attention? How alliance announcements and alliance density affect analyst coverage. Strategic Organization, 2(3), 293-312.

Kang, J.-K., \& Kim, J.-M. (2010). Do foreign investors exhibit a corporate governance disadvantage? An information asymmetry perspective. Journal of International Business Studies, 41(8), 1415-1438.

Kirkulak, B., \& Davis, C. (2005). Underwriter reputation and underpricing: Evidence from the Japanese IPO market. Pacific-Basin Finance Journal, 13(4), 451-470.

Kotter, J., \& Lel, U. (2011). Friends or foes? Target selection decisions of sovereign wealth funds and their consequences. Journal of Financial Economics, 101(2), 360-381.

Kutsuna, K., Dimovski, W., \& Brooks, R. (2008). The pricing and underwriting costs of Japanese REIT IPOs. Journal of Property Research, 25(3), 221-239.

Lenihan, A. T. (2014). Sovereign Wealth Funds and the Acquisition of Power. New Political Economy, 19(2), 227-257.

Liang, K.-Y., \& Zeger, S. L. (1986). Longitudinal data analysis using generalized linear models. Biometrika, 73(1), 13-22.

Loughran, T., \& Ritter, J. R. (2004). Why has IPO underpricing changed over time?. Financial Management, 33(3), 5-37.

Megginson, W. L., \& Weiss, K. A. (1991). Venture capitalist certification in initial public offerings. The Journal of Finance, 46(3), 879-903.

Moeller, S. B., \& Schlingemann, F. P. (2005). Global diversification and bidder gains: A comparison between cross-border and domestic acquisitions. Journal of Banking E Finance, 29(3), 533-564. 
Nicholson, S., Danzon, P., \& McCullough, J. (2005). Biotech-Pharmaceutical Alliances as a Signal of Asset and Firm Quality. The Journal of Business, 78(4) , 1433-1464.

Park, H. D., \& Patel, P. C. (2015). How Does Ambiguity Influence IPO Underpricing? The Role of the Signalling Environment. Journal of Management Studies, 52(6), 796-818.

Qi, J., Sutton, N. K., \& Zheng, Q. (2013). The Value of Strategic Alliances in Acquisitions and IPOs. Financial Management, 44(2), 387-430.

Ragozzino, R., \& Blevins, D. P. (2016). Venture-Backed Firms: How Does Venture Capital Involvement Affect Their Likelihood of Going Public or Being Acquired? Entrepreneurship Theory and Practice, 40(5), 991-1016.

Ragozzino, R., \& Reuer, J. J. (2007). Initial public offerings and the acquisition of entrepreneurial firms. Strategic Organization, 5(2), 155-176.

Reuer, J. J., Tong, T. W., \& Wu, C.-W. (2012). A signaling theory of acquisition premiums: Evidence from IPO targets. Academy of Management Journal, 55(3), 667-683.

Rubbaniy, G., Shahzad, K., \& Zahir-ul-Hassan, M. K. (2018). Signaling Theory of Acquisition Premium: A Cross-Sectional Analysis from AsiaPacific. Available at SSRN: https://ssrn.com/abstract=3181594

Scitovsky, T. (1954). Two concepts of external economies. Journal of Political Economy, 62(2), 143-151.

Spence, A. M., \& Michael, A. (1974). Market signaling: Informational transfer in hiring and related screening processes. Cambridge, MA: Harvard University Press..

Spence, M. (1978). Job market signaling. In Uncertainty in Economics (pp. 281-306): Cambridge: Academic Press.

Sullivan, M. J., \& Unite, A. A. (2001). The influence of group affiliation and the underwriting process on emerging market IPOs: The case of the Philippines. Pacific-Basin Finance Journal, 9(5), 487-512. 
Truman, E. M. (2009). A blueprint for sovereign wealth fund best practices. Revue d'economie Financiere, 9(1), 429-451.

Varaiya, N. P. (1987). Determinants of premiums in acquisition transactions. Managerial and Decision Economics, 8(3), 175-184.

Vasudeva, G., Nachum, L., \& Say, G.-D. (2017). A Signaling Theory of Institutional Activism: How Norway's Sovereign Wealth Fund Investments Affect Firms' Foreign Acquisitions. Academy of Management Journal, 61(4), 1583-1611.

Walkling, R. A., \& Edmister, R. O. (1985). Determinants of tender offer premiums. Financial Analysts Journal, 41(1), 27-37.

Welch, I. (1989). Seasoned offerings, imitation costs, and the underpricing of initial public offerings. The Journal of Finance, 44(2), 421-449.

Wright, M., Lockett, A., Pruthi, S., Manigart, S., Sapienza, H., Desbrieres, P., \& Hommel, U. (2004). Venture capital investors, capital markets, valuation and information: US, Europe and Asia. Journal of International Entrepreneurship, 2(4), 305-326.

Zhao, R. W., Xiong, X., \& Shen, D. H. (2018). Investor attention and performance of IPO firms: Evidence from online searches. Physica a-Statistical Mechanics and Its Applications, 508, 342-348.

Zheng, Y. (1999). Discovering Chinese nationalism in China: Modernization, identity, and international relations. Cambridge, England:Cambridge University Press.

Zhimin , C. (2005). Nationalism, Internationalism and Chinese Foreign Policy. Journal of Contemporary China, 14(42), 35-53. 
Appendix A: List of Countries and Sectors

\begin{tabular}{|c|c|}
\hline \multicolumn{2}{|r|}{ List of Countries in Asia Pacific Region } \\
\hline Serial\# & Target Nation \\
\hline 1 & India \\
\hline 2 & Hong Kong \\
\hline 3 & Australia \\
\hline 4 & Singapore \\
\hline 5 & New Zealand \\
\hline 6 & China \\
\hline 7 & Malaysia \\
\hline 8 & Taiwan \\
\hline 9 & Philippines \\
\hline 10 & South Korea \\
\hline 11 & Thailand \\
\hline 12 & Indonesia \\
\hline 13 & Vietnam \\
\hline 14 & Sri Lanka \\
\hline \multicolumn{2}{|r|}{ List of Target Firm Economic Sectors } \\
\hline Serial\# & Target Economic Sector \\
\hline 1 & Non-Cyclical Consumer Goods / Services \\
\hline 2 & Technology \\
\hline 3 & Basic Materials \\
\hline 4 & Cyclical Consumer Goods / Services \\
\hline 5 & Utilities \\
\hline 6 & Telecommunications Services \\
\hline 7 & Energy \\
\hline 8 & Healthcare \\
\hline
\end{tabular}


